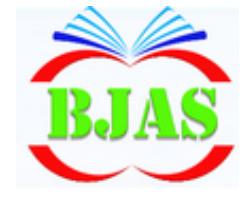

ISSN 1814 - 5868
Available online at http://bajas.edu.iq

https://doi.org/10.37077/25200860.2021.34.sp1.9

College of Agriculture, University of Basrah

Basrah J. Agric. Sci., 34(Special Issue 1): 81-91, 2021

\section{Basrah Journal \\ of Agricultural \\ Sciences}

E-ISSN: 2520-0860

\title{
Adaptive Performance Evaluation of IAR-Sorghum Thresher for Two Varieties of Wheat \\ Akintayo Afolabi ${ }^{1 *}$, Kolawole I. Oguntade ${ }^{1}$ \& Aisha Abdulkadir ${ }^{2}$ \\ ${ }^{1}$ Department of Agricultural and Bioresources Engineering, Ahmadu Bello University, Zaria, Nigeria \\ ${ }^{2}$ Department of Soil Science, Ahmadu Bello University, Zaria, Nigeria \\ *Corresponding author E-mail: kingafobi@yahoo.com
}

Others’ E-mails: scolarymoyeni2010@gmail.com; 2akad.aisha@gmail.com

Received 19 September 2019; Accepted 18 May 2021; Available online 20 August 2021

\begin{abstract}
With the aim of providing a multi-crop thresher to local farmers, the IARsorghum thresher was evaluated using varieties of wheat. Among the factors which were varied in the randomized complete block design experiments used in the evaluation were 2 levels of moisture content, 2 levels on feed rate, 3 levels of cylinder speed and 3 replications of each treatment. The indices used to measure the effectiveness and efficiency of the thresher to process wheat were threshing efficiency, cleaning efficiency, scatter loss from thresher and its output capacity. The fuel consumption rates of carrying the tasks out were also determined for the 2 moisture contents of each variety. These indices translate into the economics qualities and quantities which would influence the acceptance or other of the thresher by targeted farmers. It was found that the thresher could thresh the crop to a threshing efficiency of 95\%, cleaning efficiency of $82 \%$, scatter loss of $10 \%$ achieved by the thresher was rather high, and the output capacity of $9 \mathrm{~kg} \mathrm{hr}^{-1}$ was not satisfactorily. Hence, the recommendation on how to improve on the thresher performance and the rate of fuel consumption were provided.
\end{abstract}

Keywords: Threshing Efficiency, Cleaning Efficiency, Scatter Loss, Throughput Capacity, Hard Red Winter Wheat and Hard White wheat

\section{Introduction}

In recent time, the government of Nigeria is trying to diversify from mono economic and over dependent on petroleum to multiple economic. Agriculture remains one of the feasible sources of earning foreign exchange and employment of the populace (Benjamin \& Victoria, 2012). Maize, rice and wheat are some of the most consumed crops not only in Nigeria but also beyond. Wheat (Triticum aestivum) has been rated as the third most essential cereal crop after rice and maize in terms of the cultivated land area and metric tonnes of products, about 232 million hectares of land is used for the production of 595 million metric tonnes of wheat yearly (Mandel \& Mukhopadhyay, 2015). Nigeria has the conducive climatic condition to be a major producer of wheat and two varieties of wheat 
have been found to strive very well in certain parts of the country. These two varieties are the hard red winter and hard white wheats (FAO, 2009). Some of the states in Nigeria where wheat are popularly grown are Sokoto, Kano, Kaduna, Zamfara, Katsina states. Wheat forms some of the food crop eaten in household in the country as tuwo, fura and danwake. Industrially, flour from wheat can be used for making of bread, cakes, noodle, biscuits and other confectionaries. Wheat is a good source of carbohydrate; it is also source of vegetative protein for human with $13 \%$ protein (CORDIS, 2016). People on special diet have always been advised to consume wheat products. Brad and other residues of wheat can be used as animal feed.

Despite the economic and nutritive importance of wheat and Nigeria's potential for its production, only 90000 tonnes of wheat is produced in the country while 4000000 tonnes are consumed in the same country annually (Adetokunbo et al., 2017). Some of the factors for the low production of wheat in Nigeria are low capital investment in agriculture, small farmland hold, low level of mechanized farming, lack of properly fitted farming equipment for the crop production and processing, among others. Because of the high capital cost of purchasing a combine harvester, an average wheat farmer in the country cannot afford to purchase and maintain one; thus uses manual labour entirely for the production of the crop. The farmers harvest the produce using handheld sickles and thresh it either by pounding the harvested ear head in mortal using pestle or flailing the product in sizeable sacks or on paved floors after which women are engaged to winnow the threshed crop for the purpose of cleaning and separating the kernels from the chaff. The important factors which affect threshing of crops are variety of the crops, the degree of dryness and the method of threshing (Danilo \& Beverley, 1999). Mande (2011) and Afolabi et al. (2019) reported that manual threshing and cleaning of crops are time-consuming, labour intensive, reduces quality of product, causes contamination by the inadvertent introduction of foreign material and discourages the production of the crop by local farmers. Besides cultivation of wheat, local farmers also plant other cereals. Hence the farmers would value a single machine which may be used for the processing of more than one of their produces. The aim of this study is to investigate the suitability of Institute of Agricultural Research (IAR) Sorghum Thresher for wheat and to give recommendation for its redesign to become a multi-crop thresher for sorghum, wheat and possibly rice. This is aimed at improving the living standard of local farmers by increasing the market values of the produces, reduce drudgery of threshing and cleaning the farm produce and lower the cost of the production by handling down to the local farmers a multi-crop thresher.

\section{Materials \& Methods}

\section{Materials selection}

The materials used for the evaluation were: the existing IAR-sorghum thresher, digital tachometer (DT2235B), E200 electronic weighing balance of sensitivity of $0.01 \mathrm{~kg}$, Eijkelkamp oven dryer, quartz stopwatch, and two varieties of unthreshed wheat varieties namely, hard white wheat and hard red winter wheat. Each of the varieties of wheat was purchase from a local farmer in Karfi village of 
Kura Local Government Area in Kano state who cultivated it.

\section{Determination of moisture content of grains}

The moisture contents of the wheat varieties were determined using the standard oven-dried method (ASAE, 1998). The initial and final weights of the two varieties of wheat before and after oven-drying were measured using the electronic weighing balance. Threshed wheat grains of the two varieties were oven-dried at $105^{\circ} \mathrm{C}$ for 24 hours (Ndirika, 1994; Afolabi et al., 2019). Two levels of crop moisture contents for each variety were used for the performance evaluation of the IAR sorghum thresher. The moisture contents were 4.4 and $3.6 \%$ dry basis (for red wheat) and 4.7 and $4.0 \%$ dry basis (for white wheat), these were the natural moisture contents of the varieties; the upper and the lower moisture contents for each variety were its values 2 and 3 weeks respectively of storage after harvest.

The expression used for the determination of the moisture contents was as given by Mohsenin (1980) and ASAE (1998):

$M_{C}=\frac{W 1-W 2}{W 2} \times 100 \% \quad 1$

Where; $M_{C}=$ crop moisture content $(\%)$

$\mathrm{W}_{1}=$ weight of grains before oven-drying $(\mathrm{kg})$

$\mathrm{W}_{2}=$ weight of grains after oven-drying $(\mathrm{kg})$

\section{Determination of cylinder speed}

The cylinder speeds of the thresher during its performance evaluation were measured using the tachometer. The thresher was evaluated at three set levels of cylinder speeds of 600, 700 and 800 revolutions per minute (corresponding to peripheral speed of $11.0,12.8$ and $14.6 \mathrm{~ms}^{-1}$ respectively). These three levels of cylinder speeds were used to evaluate both varieties of wheat. The speeds were selected based on the speed required to thresh the crop effectively without unnecessarily overturning the machine after preliminary test.

\section{Determination of feed rate}

The feed rates of the thresher were determined by weighing out 0.4 and $0.6 \mathrm{~kg}$ of the unthreshed wheat at the stated moisture contents. These masses of the un-threshed crop were measured using the E200 electronic weighing balance. The time to manually feed in the weighted masses of the wheat crop into the thresher were measured with the quartz stopwatch and converted into kilogramme per hour $\left(\mathrm{kg} \mathrm{hr}^{-1}\right)$. The feed rates of 24 and $36 \mathrm{~kg}$ $\mathrm{hr}^{-1}$ were therefore used for the evaluation of the thresher. These feed rates were selected based on the quantity of un-threshed crop available and the mass of un-threshed crop that a man (operator) can manually and conveniently feed into the thresher through the chute per unit time.

\section{Performance evaluation parameters of the IAR sorghum thresher}

In order to evaluate the performance of the IAR sorghum thresher, selected evaluation indices were considered:

\section{Threshing efficiency $\left(T_{\varepsilon}\right)$}

The threshing efficiency $\left(\mathrm{T}_{\varepsilon}\right)$ is defined as the percentage ratio of the threshed grain to the total quantity of sample grain after a threshing process. It is given by Kumar et al. (2016) and Afolabi et al. (2019) as:

$\mathrm{T}_{\varepsilon}=100-\frac{Q u}{Q t} \times 100$

Where; $\mathrm{T}_{\mathrm{E}}=$ Threshing efficiency $(\%)$ 
$\mathrm{Q}_{\mathrm{U}}=$ Mass of unthreshed earhead in a sample $(\mathrm{kg})$

$\mathrm{Q}_{\mathrm{T}}=$ Total mass of the sample (unthreshed and threshed in $\mathrm{kg}$ )

\section{Cleaning efficiency $\left(\mathrm{C}_{\varepsilon}\right)$}

The cleaning efficiency $\left(\mathrm{C}_{\varepsilon}\right)$ is the ratio by weight of the pure grains collected at grain outlet to the total weight of the chaff and grains collected at the same outlet expressed in percentage. The equation is given by Gbabo et al. (2013) and Kumar et al. (2016) as:

$\mathrm{C}_{\varepsilon}=\frac{W t-W c}{W t} \times 100$

Where; $\mathrm{C}_{\varepsilon}=$ cleaning efficiency $(\%)$

$\mathrm{W}_{\mathrm{t}}=$ total weight of grain and chaff collected at the outlet $(\mathrm{kg})$ and,

$\mathrm{W}_{\mathrm{C}}=$ weight of chaff only collected at the outlet $(\mathrm{kg})$

\section{Scatter losses $\left(\mathbf{S}_{\ell}\right)$}

During the operation, some grains were lost as scatter loss from the thresher; there were not collected with others at the grains outlet. The equation use to determine scatter losses from the thresher was given by Ndirika (1994) and Kumar et al. (2016) as:

$\mathrm{S}_{\ell}=\frac{Q l}{Q t} \times 100$

Where; $\mathrm{S}_{\ell}=$ scatter loss $(\%)$

$\mathrm{Q}_{1}=$ the quantity of grains scattered from machine $(\mathrm{kg})$

$\mathrm{Q}_{\mathrm{t}}=$ total quantity of grains threshed $(\mathrm{kg})$ (scattered plus grains collected at collector)

\section{Throughput capacity $\left(\mathbf{T}_{\mathrm{c}}\right)$}

Throughput capacity of the thresher is expressed as the total quantity of cleaned grains collected at grains outlet per unit threshing time. The equation is given by Kumar et al. (2016) as:

$\mathrm{T}_{\mathrm{C}}=\frac{Q}{T}$

Where; $T_{c}=$ throughput capacity $\left(\mathrm{kg} \mathrm{min}{ }^{-1}\right)$

$\mathrm{Q}=$ quantity of grain collected $(\mathrm{kg})$

$\mathrm{T}=$ time taken for complete operation (min).

However, throughput was converted to $\mathrm{kg} / \mathrm{hr}$ in order to determine the quantity of grain that the thresher can process per hour.

\section{Germination viability $(G v)$}

Viability was evaluated by planting the two varieties of threshed wheat grains in small transparent containers. The equation used to evaluate the germinate rate was given by Roberts (1988) as;

Germination rate $=\frac{\text { Germinated seeds } x 100}{\text { Total } \text { number of seeds }}$

6

\section{Fuel consumption $\left(F_{C}\right)$}

Fuel consumption was evaluated to determine the amount of energy that would be needed to thresh a unit mass of each of the varieties of wheat at each of the two levels of moisture contents. This was done to ease the difficulty of measuring the fuel per treatment as the amount of fuel consumption per treatment was infinite.

\section{Experimental procedure and design}

The performance evaluation of the IARsorghum thresher using wheat varieties (hard red winter wheat and hard white wheat) was carried out at the Department of Agricultural and Bioresources Engineering, Ahmadu Bello University, Zaria, Nigeria. The weighed masses of unthreshed wheat were fed into the thresher 
per unit time for the machine to perform its two simultaneous tasks of threshing and cleaning the grains while discharging the desired product at the grains outlet and blowing off the chaff and other unwanted materials. The evaluation was carried out using the Randomized Complete Block Design (RCBD) in which four parameters were considered viz; 2 varieties of wheat, each at 2 levels of moisture contents, 2 levels of manual feed rates, 3 levels cylinder Speed (Tables 1) and 3 replications of each treatment. The effects of the variation of each of the 4 independent factors and their interactions on the performance of the thresher were evaluated using the analysis of variance (ANOVA) and Duncan Multiple Range test (DMRT). The DMRT was only used to rank the means of the dependent parameters where they were either significant or highly significant. Plate (1) shows the thresher during its performance evaluation.

Table (1): Levels of variables used for thresher evaluated.

\begin{tabular}{ll}
\hline Variables & Values of Levels \\
\hline varieties' nature moisture contents (\%) & $3.6,4.4$ (hard red winter wheat variety) \\
& $4.0,4.7$ (hard white wheat) \\
Feed rate $\left(\mathrm{kg} \mathrm{hr}^{-1}\right)$ & 24,36 \\
Cylinder speed $\left(\mathrm{ms}^{1}\right)$ & $11.0,12.8,14.6$ \\
\hline
\end{tabular}

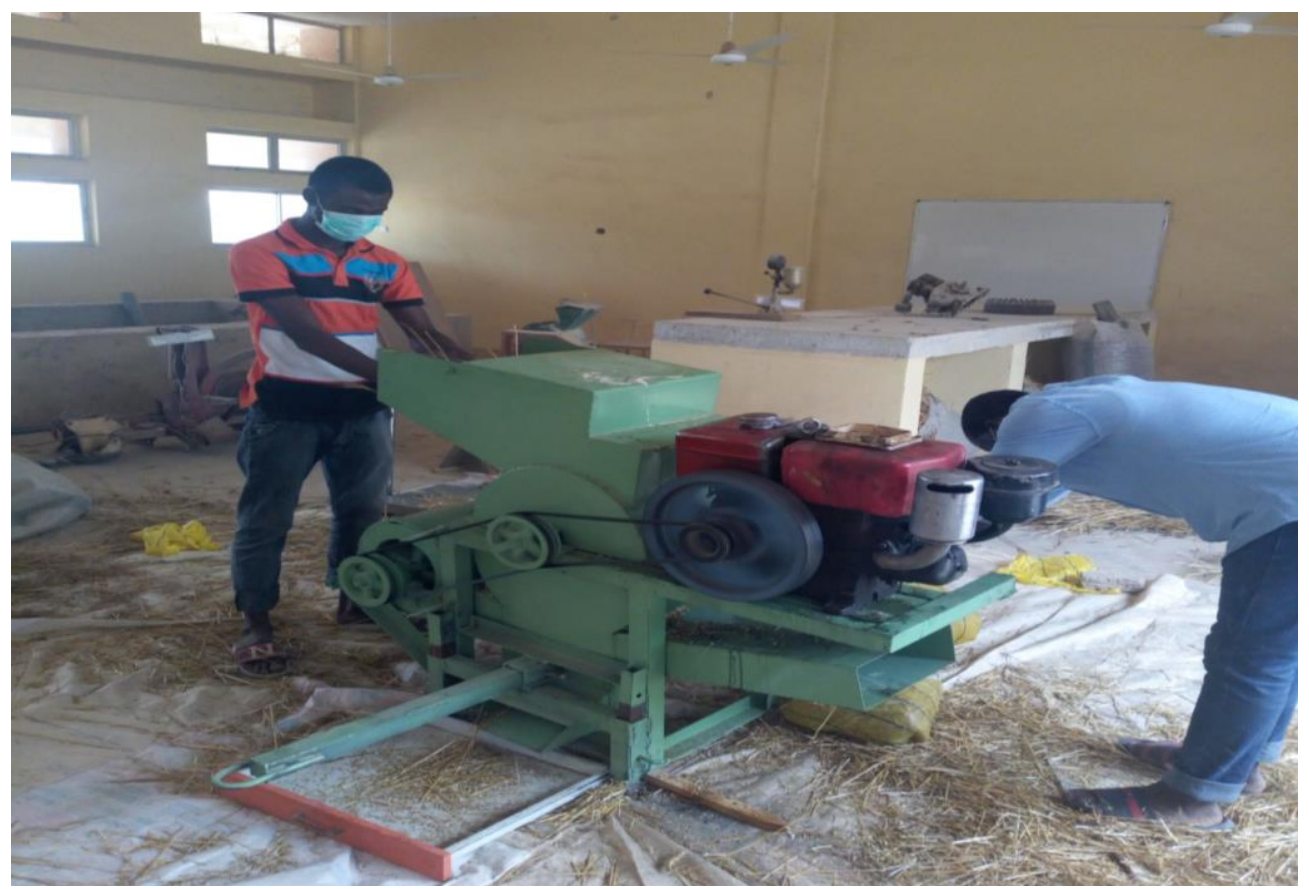

Plate (1): The thresher during its performance evaluation. 


\section{Results \& Discussion}

\section{Performance evaluation}

Table 2 presents the F-values obtained from the ANOVA for threshing and cleaning efficiencies, scatter losses and throughput capacity investigated, and Table 3 shows the DMRT, where needed. The results show that there is no significant difference in the replications of the experiments which means that there was no biasedness in the treatment. From Table 1, the interaction of all the four independent factors namely, variety, moisture content, cylinder speed and feed rates are not significant. This implies that all the four main effects were not being influenced by their interactions (Walpole et al., 2010). These lend credence to the ANOVA results of the main effects for all the test parameters investigated.

The F-values of the moisture content show that the levels of moisture content of the crop have no significant effect on all the tested parameters. This implies that the moisture contents evaluated are adequate for the threshing and cleaning of the crop using the thresher. The F-values of feed rate for threshing and cleaning efficiencies were found to be 0.13 and 0.12 respectively which imply that the feed rates is not significant to these efficiencies obtain from the thresher. The F-value of scatter loss for feed rate was gotten as 5.09 and indicates that the feed rate is significant (at 5\% level of confidence) to the scatter loss from the thresher. The F-value of 182.81 for feed rate on throughput indicates that the feed rate is highly significant to the throughput from thresher. Table (3) shows that the scatter loss decreases with the feed rate while the throughput increases with the feed rate.
For variety, the threshing efficiency with $\mathrm{F}$ value of 5.17 was highly significant (at $1 \%$ level of confidence). This means that the thresher does not thresh the varieties with equal efficiency. Table 3 shows that the hard white variety has high threshing efficiency of $95.55 \%$ and the hard red winter wheat variety was threshed with the lower means efficiency of 94.8\%. However, the sorghum thresher was able to thresh the two varieties of wheat to an efficiency of about $95 \%$. The result of Table 2 also reveals that the scatter loss from the thresher was highly significant to the variety of wheat. Table (3) shows that the loss of hard red winter variety is lower with the mean value of $8.54 \%$ as compared with $10.9 \%$ scatter loss for hard white variety. For throughput capacity on variety, the F-value on table (2) is $6.89 \mathrm{~kg} \mathrm{hr}^{-1}$ and significant. Table (3) reveals that the mean throughput capacity of $7.72 \mathrm{~kg} \mathrm{hr}^{-1}$ is obtained for hard red winter wheat; this is higher than the throughput capacity of $7.27 \mathrm{~kg} \mathrm{hr}^{-1}$ obtained for red winter wheat.

Table (2) displays only threshing efficiency was not significant to the cylinder speed; cleaning efficiency and throughput are highly significant to cylinder speed. Scatter loss is significant to cylinder speed. From Table 3, cleaning efficiency, scatter loss and throughput capacity statically vary with cylinder speed. For cleaning efficiency and scatter loss, the cylinder speed of $700 \mathrm{rpm}$ gives the highest values for each of the parameters. 
Afolabi et al. Basrah J. Agric. Sci., 34(Special Issue 1): 81-91, 2021

Table (2): ANOVA results of the Performance Evaluation of the Thresher.

\begin{tabular}{|c|c|c|c|c|c|c|c|}
\hline \multicolumn{2}{|l|}{$\mathrm{S}_{\mathrm{V}}$} & $\mathrm{D}_{\mathrm{F}}$ & $\mathrm{T}_{\varepsilon}$ & $\mathrm{C}_{\varepsilon}$ & $\mathrm{S}_{\ell}$ & $\mathrm{T}_{\mathrm{C}}$ & \\
\hline \multicolumn{2}{|l|}{ REP } & 2 & $0.45^{\mathrm{ns}}$ & $0.62^{\mathrm{ns}}$ & $0.12^{\mathrm{ns}}$ & $1.29^{\mathrm{ns}}$ & \\
\hline \multicolumn{2}{|l|}{ MOIS } & 1 & $0.39^{\text {ns }}$ & $0.27^{\mathrm{ns}}$ & $2.98^{\mathrm{ns}}$ & $0.89^{\mathrm{ns}}$ & \\
\hline \multicolumn{2}{|l|}{ FEED } & 1 & $0.13^{\mathrm{ns}}$ & $0.12^{\mathrm{ns}}$ & $5.09^{*}$ & $182.81^{* *}$ & \\
\hline \multicolumn{2}{|l|}{ VARE } & 1 & $5.17^{* *}$ & $3.10^{\mathrm{ns}}$ & $47.41^{* *}$ & $6.89^{*}$ & \\
\hline \multicolumn{2}{|l|}{ SPED } & 2 & $0.33^{\mathrm{ns}}$ & $14.82^{* *}$ & $4.73^{*}$ & $57.96^{* *}$ & \\
\hline \multicolumn{2}{|c|}{ VARE*MOIS } & 1 & $1.13^{\mathrm{ns}}$ & $0.30^{\mathrm{ns}}$ & $4.76^{*}$ & $13.24^{* *}$ & \\
\hline \multicolumn{2}{|c|}{ VARE*FEED } & 1 & $0.92^{\mathrm{ns}}$ & $0.03^{\mathrm{ns}}$ & $1.26^{\mathrm{ns}}$ & $3.32^{\mathrm{ns}}$ & \\
\hline \multicolumn{2}{|c|}{ VARE*SPED } & 2 & $2.44^{\mathrm{ns}}$ & $0.48^{\mathrm{ns}}$ & $7.24^{* *}$ & $0.80^{\mathrm{ns}}$ & \\
\hline \multicolumn{2}{|c|}{ MOIS*FEED } & 1 & $4.22^{* *}$ & $3.90^{\mathrm{ns}}$ & $0.24^{\mathrm{ns}}$ & $1.35^{\mathrm{ns}}$ & \\
\hline \multicolumn{2}{|c|}{ MOIS*SPED } & 2 & $6.67^{* *}$ & $13.19^{* *}$ & $9.65^{* *}$ & $94.68^{* *}$ & \\
\hline \multicolumn{2}{|c|}{ FEED*SPED } & 2 & $0.00^{\mathrm{ns}}$ & $4.63^{* *}$ & $2.97^{\mathrm{ns}}$ & $10.26^{* *}$ & \\
\hline \multicolumn{2}{|c|}{ VARE*MOIS*FEED } & 1 & $1.30^{\mathrm{ns}}$ & $2.73^{\mathrm{ns}}$ & $0.60^{\mathrm{ns}}$ & $2.55^{\mathrm{ns}}$ & \\
\hline \multicolumn{2}{|c|}{ VARE*MOIS*SPED } & 2 & $2.33^{\mathrm{ns}}$ & $3.14^{\mathrm{ns}}$ & $9.52^{* *}$ & $1.85^{\mathrm{ns}}$ & \\
\hline \multicolumn{2}{|c|}{ MOIS*FEED*SPED } & 2 & $3.63^{* *}$ & $0.78^{\mathrm{ns}}$ & $3.16^{\mathrm{ns}}$ & $0.39^{\mathrm{ns}}$ & \\
\hline \multicolumn{2}{|c|}{ VARE*MOIS*FEED*SPED } & 4 & $1.03^{\mathrm{ns}}$ & $1.02^{\mathrm{ns}}$ & $0.37^{\mathrm{ns}}$ & $1.98^{\mathrm{ns}}$ & \\
\hline \multicolumn{2}{|c|}{ ERROR } & 46 & & & & & \\
\hline \multicolumn{2}{|c|}{ TOTAL } & 71 & & & & & \\
\hline \multicolumn{8}{|c|}{$\begin{array}{l}\text { ignificant, } *=\text { significant }(\alpha=5 \%) 1, * *=\text { highly significant }(\alpha=1 \%), S_{\mathrm{V}}=\text { source of variation, } D_{\mathrm{F}}=\text { degre } \\
\text { MOIS }=\text { moisture content, FEED }=\text { feed rate, VARE }=\text { variety, } \mathrm{SPED}=\text { cylinder speed. }\end{array}$} \\
\hline \multicolumn{8}{|c|}{ 3): DMRT for significant and highly significant parameter of main factors } \\
\hline \multirow[t]{3}{*}{ bles } & Levels & $\mathbf{T}_{\varepsilon}$ & & & $\mathbf{S}_{\ell}$ & & $\mathbf{T}_{\mathrm{c}}$ \\
\hline & $36 \mathrm{~kg} \mathrm{hr}^{-1}$ & - & & & 9.33 & & $8.66 a$ \\
\hline & $24 \mathrm{~kg} \mathrm{hr}^{-1}$ & - & & & 10.0 & & $6.34 b$ \\
\hline \multirow[t]{2}{*}{$\mathrm{y}$} & hard red winter & 94.7 & & & 8.54 & & $7.72 \mathrm{a}$ \\
\hline & hard white & 95.5 & & & 10.8 & & $7.27 \mathrm{~b}$ \\
\hline \multirow[t]{3}{*}{ ler speeds } & $600 \mathrm{rpm}$ & - & & $0 \mathrm{~b}$ & 8.98 & & $6.25 c$ \\
\hline & $700 \mathrm{rpm}$ & - & & $6 a$ & 10.1 & & $7.18 \mathrm{~b}$ \\
\hline & $800 \mathrm{rpm}$ & - & & & 10.0 & & $8.44 \mathrm{a}$ \\
\hline
\end{tabular}

Different letters in same column of Variables are statistically not equivalent. 
But for the means values of these parameters, the cylinder speed of $800 \mathrm{rpm}$ were not statistically differ from those of $700 \mathrm{rpm}$. However, the mean values of the parameter at $600 \mathrm{rpm}$ are statically different from those of $700 \mathrm{rpm}$ and $800 \mathrm{rpm}$, which are statistically equal. For throughput capacity, table (3) shows that each cylinder speed was in its own class statistically and increased with cylinder speed. Table (2), explains the interaction of variety with any of the 3 other variables are not significant for threshing efficiency and cleaning efficiency. Furthermore, the interaction of variety and feed rate are not significant for scatter loss and throughput capacity, while the interaction of variety and feed rate is significant to scatter loss and highly significant to throughput capacity. For varieties and cylinder speed, only scatter loss is highly significant with the F-value of 7.27. For the interaction of moisture content and feed rate, only threshing efficiency with F-value of 4.22 is highly significant, while for all the dependent parameters evaluated, the interaction of moisture content and cylinder speed are highly significant. This implies that the combination of moisture content and cylinder speed is very strong factor to the performance of the thresher as the combination affects all the evaluated indicators. In the interaction of three independent factors, only scatter loss and threshing efficient are significant for the interaction of variety, moisture content and cylinder speed and the interaction of variety, cylinder speed and cylinder speed respectively. Kamble et al. (2003) and Afolabi (2015) had very similar results to those this study for the different pearl millet threshers evaluated by them in India and Nigeria respectively.
Fig. (1) shows the effect of moisture contents of hard red winter wheat on fuel consumption rate. It shows that $0.371 \mathrm{~kg}^{-1}$ of fuel was consumed at the higher crop moisture content of $4.4 \%$ and $0.411 \mathrm{~kg}^{-1}$ of fuel at the lower crop moisture content of $3.6 \%$. It is expected that the fuel consumption rate decreases as the moisture content of the crop decreases. But while fixing the breakdown experienced during the experiment at $3.6 \%$ lower moisture content, the machine consumed more quantity of fuel at lower moisture content level.

Fig. (2) shows the fuel consumption rate for hard white wheat at indicated moisture contents. The hard-white wheat consumed 0.48 $1 \mathrm{~kg}^{-1}$ of diesel having threshed the crop at the higher moisture content of $4.7 \%$ and $0.401 \mathrm{~kg}^{-1}$ of fuel at the lower moisture content of $4.0 \%$. The result is in line with the expectation based on reasoning. Fig. (3) shows the germination efficiency of both varieties of the crop used for the experiment. It indicates that hard red winter wheat has germination efficiency of $67 \%$ while hard white wheat has germination efficiency of $78 \%$ which shows that white wheat is more viable in terms of germination compared to hard red winter wheat. However, the low variability result cannot be blamed on the thresher; as hand-threshed samples of the varieties gave similar result of viability test. This is because the wheat varieties were not meant to be sold as commercial seeds. 
Afolabi et al. Basrah J. Agric. Sci., 34(Special Issue 1): 81-91, 2021

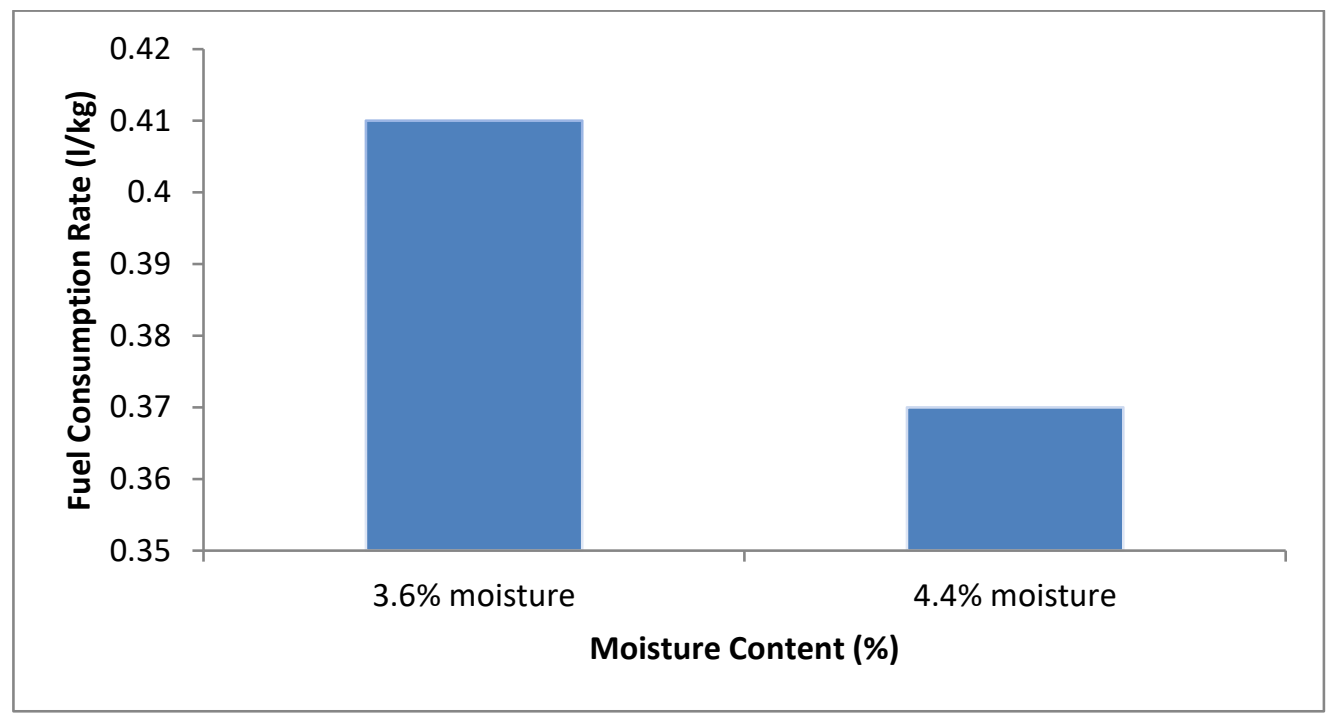

Fig. (1): Effect of moisture contents of hard red winter wheat on fuel consumption rate.

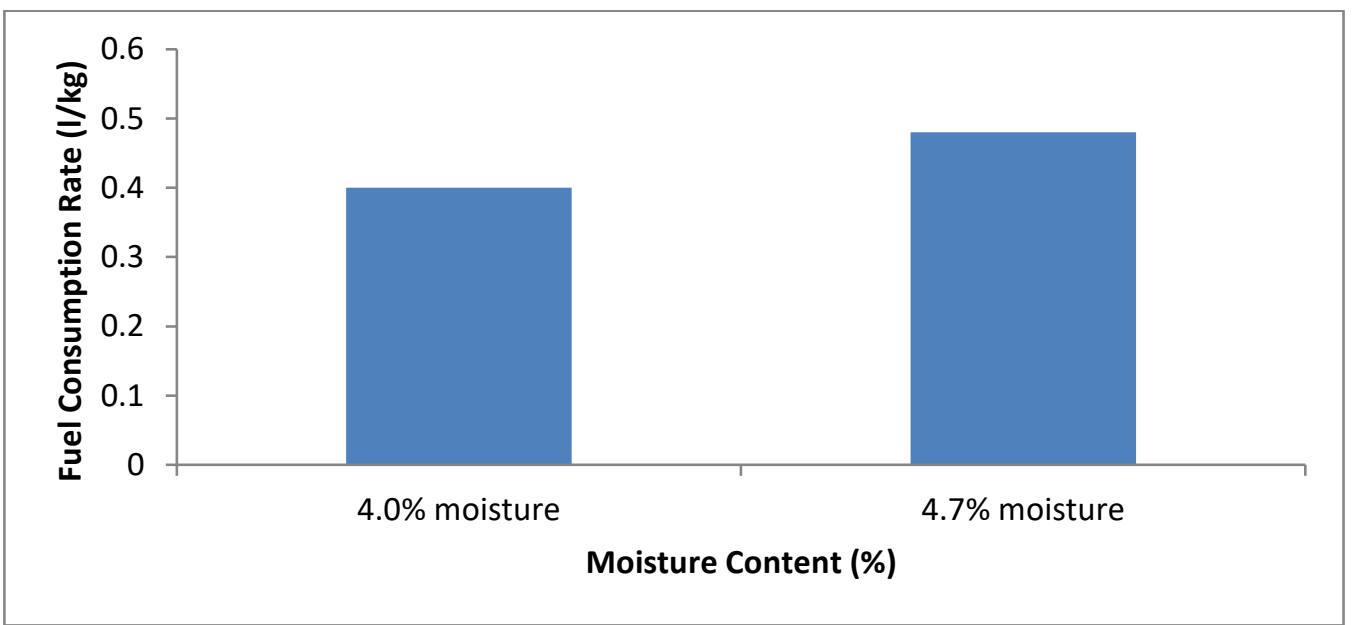

Fig. (2): Effect of moisture contents of hard white wheat on fuel consumption rate.

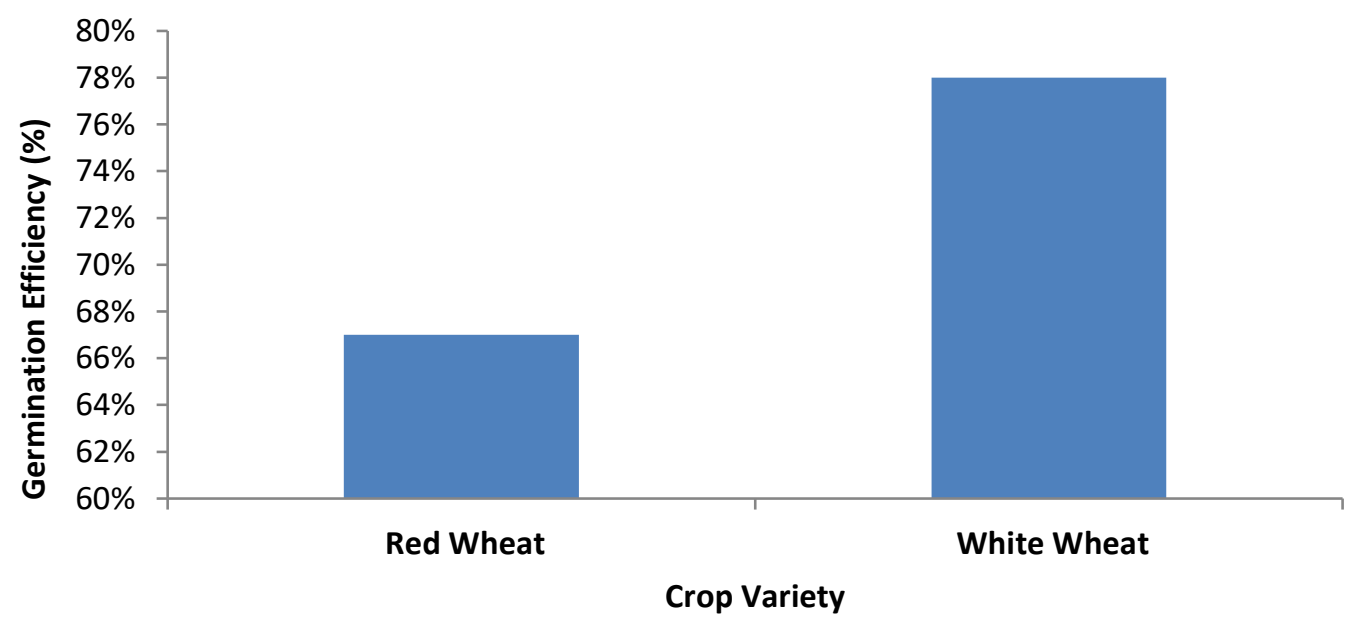

Fig. (3): Result of viability for each variety of wheat. 


\section{Conclusion}

The IAR-sorghum thresher was able to thresh wheat to about $95 \%$ threshing efficiency, $82 \%$ cleaning efficiency; however, the performance of the thresher for wheat can be improved by reducing the size of the perforation in the cylinder through which the threshed kernel fall before being cleaned. Also the chute inlet for the feeding in of unthreshed crop should be redesigned to allow for more quantity of wheat to be fed in per time. This would increase the output capacity $\left(\mathrm{kg} \mathrm{hr}^{-1}\right)$ which is presently limited due to rate of feed input of unthreshed crop, whereas the other units of the thresher have the capacity to process more much mass than can be fed in. After this recommendation, an on-field evaluation should be carried out in order to ascertain the maximum processing capability of the thresher for wheat.

\section{References}

Adetokunbo, O. A., Olubunmi, I. P., Oluwasina, G. O., \& Gloria, N. E. (2017). Rheological characteristics and baking quality of flours from Nigerian grown wheat. African Journal of Food Science 11, 376382. https://doi.org/10.5897/AJFS2017.1565

Afolabi, A., Yusuf, D. D., \& Muhammed, U. S. (2019). Performance Evaluation of an Axial-Flow Pearl Millet Thresher. Agricultural Mechanization in Asia, Africa and Latia America, 50, 41-46.

Afolabi, A. (2015). Design, Construction and Performance Evaluation of an axial-Flow Millet thresher. Unpublished MSc Thesis submitted at the Department of Agricultural Engineering, Ahmadu Bello University, Nigeria. http://kubanni.abu.edu.ng/jspui/bitstream/1234567 89/8056/1/DESIGN\%2C\%20CONSTRUCTION\% 20AND\%20PERFORMANCE\%20EVALUATIO N\%20OF\%20AN\%20AXIALFLOW\%20MILLET\%20THRESHER.pdf

America Society of Agricultural Engineers (ASAE) (1998). Standard $40^{\mathrm{TH}}$ Edition. St Joseph MI, USA. 132-143
Benjamin C. A. \& Victoria A. O. (2012). Socioeconomic Characteristics of Cereals Crop and Agricultural Development in Nigeria. International Journal of Business and Social Science, 3, 269-277.

Community Research and Information Service (CORDIS) (2016). Success wheat farming Across Africa; Published by the EU Publications Office.

Danilo M. \& Beverley L. (1999). Sorghum postharvest operations; Natural Resources Institute Chatham, Kent, England.

https://pdf4pro.com/amp/view/sorghum-food-andagriculture-organization-1a1c65.html

Food and Agriculture Organization (FAO) of United Nations (2009). Wheat Flour: Agribusiness Handbook.

http://www.fao.org/3/al376e/al376e.pdf

Gbabo, A., Ibrahim, M. G., \& Matthew, S. A. (2013). Design, Fabrication and Testing of a Millet Thresher, Journal of Agricultural Science, 1, 100106.

http://www.netjournals.org/pdf/NJAS/2013/4/13033.pdf

Kamble, H. G., Srivastava A. P., \& Pnawar J. S. (2003). Development and Evaluation of PearlMillet Thresher. Journal of Agricultural Engineering 40, 18-25. https://www.indianjournals.com/ijor.aspx?target=i jor:joae $\&$ volume $=40 \&$ issue $=1 \&$ article $=003$

Kumar, D., Kumar, A., Kalay, K., \& Singh, U. V. (2016). Performance Evaluation of Power Thresher for Wheat Crop, International Journal of Agricultural Science and Research 6, 195-204. https://www.academia.edu/28659204/PERFORM ANCE_EVALUATION_OF_POWER_THRESH ER_FOR_WHEAT_CROP

Mandel K., \& Mukhopadhyay, D. (2015). Effects of inorganic phosphorus fraction under different tillage practices on Wheat (Triticum aestivum) in an acid soil of west Bengal (India). Tropical Agrucilture Research and Extension 18, 789-899. https://doi.org/10.4038/tare.v18i3.5332

Maunde, F. A. (2011). Performance evaluation of manual cowpea thresher. African Journal of Agricultural Research, 6, 6412-6415. https://doi.org/10.5897/AJAR11.940. 
Afolabi et al. Basrah J. Agric. Sci., 34(Special Issue 1): 81-91, 2021

Mohsenin, N. N. (1980). Physical Properties of Plant and Animal Material. Gordon and Breach Science Publishers, New York. https://agris.fao.org/agrissearch/search.do?recordID=XF2015028016

Ndrikia, V. I. O. (1994). Development and performance evaluation of Millet Thresher, Journal of Agricultural Technology, 2, 80-89.

Roberts E. H. (1988). Temperature and Seed Germination of Cereal Crops. Symposia of the
Society for Experimental Biology 42, 109-132. https://pubmed.ncbi.nlm.nih.gov/3077854/

Walpole, R. E.; Myers, R. H.; Myers, S. L. \& Ye, K. (2010). Probability and statistics for engineers and scientist 9th ed. Pearson Education Inc., 432448.

http://www.elcomhu.com/Mshtrk/Statstics/9th\%20txt\%20book.pdf 